\title{
Fusarium wilt of peas (a review)
} \author{
STATION de GENETIQUE \\ JM Kraft \\ et d'AMELIORATION des PLANTES \\ INRA B.V. 1540 \\ 21034 DIJON CEDEX \\ FRANCE
}

MINISTERE de L'AGRICULTURE

US Department of Agriculture, Agricultural Research Service, RR 2 Box 2953A, Prosser, WA 99350-9687, USA

(Received 12 June 1994; accepted 3 January 1995)

\begin{abstract}
Summary - Pea wilt was first described in 1925 and the pathogen identified as Fusarium oxysporum $f$ sp pisi race 1 in 1929. Three additional races have been described and characterized as races 2, 5 and 6 . Resistance to all 4 races is governed by separate, single dominant genes in the host. Current classification of pathogen races is based on host response using differential cultivars and defined, reproducible, inoculation procedures. Recent molecular techniques, using RFLPs and RAPDs, have detailed the genetic similarities and differences among races of this pathogen. Vegetative compatibility groupings of pathogen isolates have also characterized pathogen isolates based on fungal genetics rather than host-pathogen interactions. This paper also describes the host-parasite interactions and briefly discusses what little is known about seed transmission of the pea wilt pathogen.
\end{abstract}

Résumé - Fusariose du pois. Revue. La fusariose du pois, causée par Fusarium oxysporum Schlecht f sp pisi (Van Hall) Snyd et Hans, a été signalée dans tous les pays où le pois est cultivé commercialement (Haglund, 1984). La maladie est souvent sévère là où on pratique des rotations courtes avec d'autres cultures. Dans ces conditions, quand le pathogène a développé des quantités suffisantes d'inoculum et qu'on plante un cultivar sensible, il en résulte des pertes sévères. Les symptômes sur la plante consistent en folioles chlorotiques, qui s'enroulent vers la base et deviennent flasques. Les plantes finissent par se flétrir et deviennent jaune brun. Souvent le système vasculaire aérien et souterrain devient jaune clair à rouge brique et la partie souterraine de la tige devient plus grosse que la normale.

\section{INTRODUCTION}

Wilt of peas (Pisum sativum L), caused by Fusarium oxysporum Schlecht $\mathrm{fp}$ pisi (Van Hall) Snyd and Hans, has been reported in every country where peas are grown commercially (Haglund, 1984). The disease is often severe where short rotations with other crops are practiced. Under these conditions, when the pathogen has built up sufficient inoculum numbers, and a susceptible cultivar is planted, severe crop losses result. Plant symptoms consist of chlorotic leaflets, which curl downward and become flaccid. The plant eventually wilts and turns a yellowish-brown color. Often, the aboveand below-ground vascular system turns a light yellow to brick-red color and the lower subterranean portion of the stem becomes larger than normal. 


\section{DISEASE DESCRIPTION AND HISTORY}

This disease was first described and distinguished from Fusarium root rot by Jones and Linford (1925), who named it "an undescribed wilt disease". At that time, the disease was found in 50 fields in Wisconsin, and caused greater losses in some areas than those reported for root rot. The causal organism was named $F$ othoceras App and Wr var pisi in 1928 (Linford, 1928). The pathogen was later named race 1 of $F$ oxysporum Schl $f$ sp pisi (van Hall) Snyd and Hans in 1935 (Goth and Webb, 1981). Resistance was quickly found and the introduction of wilt resistant varieties gave complete control. Wade (1929) determined that resistance to race 1 was inherited as a single dominant gene. Race 1 was not an economic problem in the United States again until 1972 (Kraft et al, 1974). Race 1 has not been eliminated but the disease is under control through the growing of resistant cultivars.

In 1933, Snyder described a new race of $F$ oxysporum that was capable of wilting plants resistant to race 1 , and they labeled the pathogen race 2. The disease was called 'nearwilt' because it appeared later in the growing season, often only at full pod development. Near wilt is as widespread as race 1 (Haglund, 1984). Plants infected with race 2 are most often scattered throughout the field rather than being concentrated in specific areas as with race 1 . In addition, race 2 is most prevalent in coarser textured soils when soil temperatures are near $25^{\circ} \mathrm{C}$. Because symptoms caused by the race 2 pathogen do not usually occur until plant maturity, the likelihood of seed transmission is greatly increased.

Hare et al (1949) determined that resistance to race 2 was also controlled by a single, separate, dominant gene not linked with the race 1 resistance gene. Delwiche Commando was the first cultivar developed possessing resistance genes for both races 1 and 2 (Goth and Webb, 1981).

Races 3 and 4 were described in the Netherlands and Canada, respectively (Schreuder, 1951; Bolton et al, 1966). However, it seems likely that races 3 and 4 are more virulent cultures of race 2 (Huebbeling, 1974). The genetic basis for resistance to races 3 and 4 was not determined. In 1970, race 5 was described in northwestern Washington (Haglund and Kraft, 1970), where all commercial cultivars resistant to races 1 and 2 were susceptible. Because of the short crop rotations and favorable climate in that area for wilt development, race 5 spread rapidly and currently affects ca 4000 to 12000 ha planted to peas each year. Resistance to race 5 was also attributed to a single dominant gene factor in the host.

In 1979, a new race of wilt was again described from western Washington, which was pathogenic on cultivars and breeding lines resistant to races 1,2 and 5 , and was named race 6 (Haglund and Kraft, 1979). The pathogen was first observed in 1971, and by 1977 was recovered from 175 of 640 fields examined. The pathogen was widespread and pathogenicity tests using differential cultivars possessing single dominant gene resistance to races 1,2 and 5 were susceptible. In genetic studies of inheritance, resistance was again attributed to a single dominant gene.

The pathogenicity of races $1,2,5$ and 6 of $F$ oxysporum $\mathrm{f} \mathrm{sp}$ pisi can be distinguished by their reaction on the differential varieties listed in table I. The disease reaction of these differentials is based on a resistant response (no observable disease) and a susceptible reaction (dead or severely stunted, chlorotic plants). The use of differential cultivars to differentiate races of $F$ oxysporum $f \mathrm{sp}$ pisi is essential (Haglund, 1974). It is recommended that these differentials be maintained as selections of the variety and not be obtained commercially to ensure their predicted disease reactions.

Classification of isolates of $F$ oxysporum $f \mathrm{sp}$ pisi based on host-pathogen interactions is governed by the genetic makeup of both the host and pathogen. The availability of cultivars to differentiate strains of the pathogen is also of concern. To further complicate matters, virulence tests are subjective because they are influenced by temperature, host age, method of inoculation, etc. Work by Puhalla (1985), as summarized by Correll (1991), has classified strains of $F$ oxysporum based on vegetative compatibility groupings (VGC). Isolates of $F$ oxysporum can be tested for vegetative compatibility by pairing nitrate nonutilizing (nit) mutants that are generated on a $1.5-4.0 \%$ potassium chlorate medium. Strains, races or subspecific groups of $F$ oxysporum may possibly be further characterized based on fungus genetics along with host--pathogen interactions

Within $F$ oxysporum $f \mathrm{sp}$ pisi, 4 VGCs have been reported. Isolates of races 1 and 6 are both reported to be in a single VGC, race 5 is in a second VGC, and race 2 isolates occur in at least 2 additional VGCs. The pattern of genetic diversity identified within a given forma specialis may have 
Table I. Suggested pea lines to differentiate races of the Fusarium wilt fungus.

Pea line

$\begin{array}{lll} & R 1 & R 2 \\ & & \\ \text { M410 } & \mathrm{S} & \mathrm{S} \\ \text { Vantage } & \mathrm{R} & \mathrm{S} \\ \text { Mini } & \mathrm{S} & \mathrm{R} \\ \text { Mini 93 } & \mathrm{R} & \mathrm{R} \\ \text { Sundance II } & \mathrm{R} & \mathrm{S} \\ \text { Grant } & \mathrm{R} & \mathrm{S} \\ \text { WSU 23 } & \mathrm{R} & \mathrm{R} \\ \text { WSU 28 } & \mathrm{R} & \mathrm{S} \\ \text { 74SN5 } & \mathrm{R} & \mathrm{R}\end{array}$

R5 R6

$\begin{array}{ll}\text { S } & \text { S } \\ \text { S } & \text { S } \\ \text { S } & \text { S } \\ \text { S } & \text { S } \\ R & S \\ S & R \\ R & \text { S } \\ R & R \\ R & R\end{array}$

Source ${ }^{a}$

Brotherton Seed Co
Brotherton Seed Co
Asgrow Seed Co
Asgrow Seed Co
Pure Line Seed Co
Brotherton Seed Co
WA Haglund
WA Haglund
JM Kraft

a Brotherton Seed Co Inc, Moses Lake, WA, USA; Asgrow Seed Co, Twin Falls, ID, USA; Pure Line Seeds Inc, Moscow, ID, USA; WA Haglund, NW Washington Research and Extension Unit, Washington State University, Vernon, WA, USA.

direct bearing on breeding for resistance. For example, race 2 belongs to at least 2 different VGC groups, which indicates possible genetic differences in virulence, survival, etc. Elucidation of genetic diversity of formae speciales in virulence interactions with particular host genotypes requires further study. This technique, coupled with molecular techniques (Coddington et al, 1987; Kistler et al, 1991), should aid our understanding of the population biology, pathology, and race (strain) relationships of this fungus.

Coddington et al (1987) studied several race 2 and 6 isolations of $F$ oxysporum $\mathrm{f} \mathrm{sp}$ pisi. Total DNA was purified, digested separately with restriction endonucleases, and DNA fragments separated by gel electrophoresis. The patterns obtained from the race 2 isolates were identical for a given enzyme as were the patterns for the race 6 isolates. Interestingly, the classification of isolates of $F$ oxysporum $f \mathrm{sp}$ pisi into races by restriction enzyme digestion patterns correlated well with the pathogenicity-host response patterns of each race studied.

Recently, randomly amplified polymorphic DNA typing (RAPDs) has been applied to fungal genetic studies (Williams et al, 1990). Work at Washington State University (M Grajal, personal communication) has related RAPDs to the genetic diversity among the 4 races of $F$ oxysporum $f$ $\mathrm{sp}$ pisi. The relatedness and possible phylogeny of different races was also studied. It appears that races 1, 5 and 6 are closely related and that race 2 is distinct. All isolates of race 2 exhibited a highly conserved banding pattern whereas isolates of the other races exhibited more variability with the primers used.

\section{INOCULATION AND SCREENING PROCEDURES}

There has been considerable disagreement in the literature on the race classification scheme of $F$ oxysporum $f \mathrm{sp}$ pisi (Armstrong and Armstrong, 1974; Haglund, 1974; Kraft and Haglund, 1978). The only sure way to determine the race classification of any isolate is the host-pathogen response. Inoculation procedures, genetic purity of the host and pathogen, environmental conditions, and inoculum levels all directly affect the host-pathogen response. It is important to standardize all these variables so that repeatable results are the norm (Huebbeling, 1974; Kraft and Haglund, 1978). Techniques to screen peas for resistance to wilt include: 1) pruning roots while submersed in a conidial suspension (Wells et al, 1949; Haglund, $1989)$; 2) pouring mycelial fragments and conidia into a trough adjacent to seedling roots growing in sand (Armstrong and Armstrong, 1974); and 3) pouring conidia and hyphal fragments into holes punched in soil with a pointed rod to wound roots (Doling, 1963). 
In Washington state, resistance of numerous breeding lines to Fusarium wilt caused by $F$ oxysporum $\mathrm{f} s p$ pisi race 1 is determined under field conditions at Pullman, WA, in cooperation with $F$ Muehlbauer, USDA/ARS, who has established a race 1 field nursery. As described by Wade (1929), elimination of the susceptible controls by race 1 wilt is complete, when inoculum levels are high, which greatly reduces or eliminates the chances for escapes. This is indeed the case at the field nursery at Pullman, WA. Resistance to race 1 as well as races 2,5 and 6 is also determined in pure culture under greenhouse conditions. Care is taken to screen for resistance to race 2 when ambient greenhouse temperatures are $20-24^{\circ} \mathrm{C}$ (Wells et al, 1949). Screening tests for races 1,5 and 6 are conducted in the winter months when ambient greenhouse temperatures range from $15-21^{\circ} \mathrm{C}$. To ensure pure cultures of the pathogen, nodal tissue from above the fourth node can be surface disinfested and plated on Nash and Snyder's PCNB (1962) or Komada medium (1975).

Wild-type cultures, used as primary inoculum, are derived from single spores on $2 \%$ water agar, increased on fresh PDA under fluorescent light with a 12-h photoperiod, and stored in autoclaved soil tubes (Toussoun and Nelson, 1976). Primary inoculum of a test isolate is produced by dispersing a small amount of infested soil on a PCNB plate (Nash and Snyder, 1962) and a resulting colony is selected, which is representative of the wild type for each race (Haglund, 1974). A small agar plug from the colony margin, after a 5-d incubation period under constant fluorescent illumination, is cut and removed with a No 6 cork borer, and placed in $50 \mathrm{ml}$ of liquid medium (Kerr, 1963). Inoculated flasks are incubated for $5 \mathrm{~d}$ on a rotary shaker (120 cycles/min) with constant fluorescent light on a laboratory bench. At that time, spore concentrations for each isolate are determined with a haemocytometer. We usually combine 3 isolates of the same race for any wilt screening test so that the final combined spore concentration is $1 \times 10^{6}$ conidia $/ \mathrm{ml}$.

Seed of each test line is surface-disinfested with a $10 \%$ chlorox solution for 1 min before planting in coarse, autoclaved perlite. All seedlings are inoculated in the third or fourth node stage by carefully removing each plant, dipping and excising one-half of the root system of each plant with a razor blade while immersed in a conidial suspension. Inoculated seedlings are transplanted back into the planting medium and incubated on a greenhouse bench $\left(20-23^{\circ} \mathrm{C}\right)$ until wilt symptoms are evident and/or known susceptible inoculated controls are dead. Wilt symptoms consist of stunting, yellowing, dying of lower leaves, downward curling of leaf margins, and usually death of the plant (Kraft and Haglund, 1978). The pathogen is readily isolated from the above-ground stem of any susceptible, inoculated plant when whole plant symptoms are evident. New races or strains of the pea wilt fungus will probably appear, especially where peas are grown in short rotations or in monoculture.

Suggested pea lines to differentiate races of pea wilt are shown in table I. These lines are maintained by the author in a pure state.

\section{HOST-PATHOGEN INTERACTIONS}

Most formae speciales of $F$ oxysporum exist as chlamydospores, which are dormant in decaying host tissue and soil until stimulated to germinate (Nelson, 1981). Root exudates are reported to be responsible for chlamydospore germination of several root rot and wilt pathogens (Huisman, 1982). No differences have been reported in germination of race 1 or 2 macroconidia, chlamydospore, or germtube growth in the spermosphere or rhizoplane of resistant or susceptible cultivars (Whalley and Taylor, 1976). However, it was reported that the total population of races 1 and 5 increased more in the rhizosphere of a susceptible rather than a resistant pea cultivar (Kraft, 1978; Charchar and Kraft, 1989).

It is apparent from earlier studies that $F$ oxysporum is an efficient soil saprophyte and root colonizer, and may also infect epidermal and cortical cells of many nonhost or resistant plants which remain symptomless. Schippers and Voetberg (1969) found no differences in chlamydospore germination of $F$ oxysporum $\mathrm{f} \mathrm{sp}$ pisi race 1 on susceptible or resistant pea seedling roots. Likewise, Charchar and Kraft (1989) reported that races 1 and 5 colonized root-surface cells of both genotypes resistant to races 1 and 5 as well as resistant and susceptible pea plants. Root surfaces of susceptible pea plants, however, supported larger populations of Fusarium colonies.

Pathogenic forms of $F$ oxysporum are reported to penetrate a host root either through wounds or directly through root apices (Nelson, 1981). The most common points of entry into the pea plant by the Fusarium wilt pathogen are the undifferentiated region of the root tips, the cotyledonary node, or wounded roots (Walker, 1935; Virgin and Walker, 1940; Doling, 1963; Nyvall and 
Haglund, 1972). The infection of a susceptible pea plant can be inter- or intracellular until the xylem elements are invaded (Beckman, 1987). In advanced stages of disease development, the wilt fungus grows out of the vascular system and into the adjacent parenchyma producing conidia and chlamydospores. The life cycle is repeated when the chlamydospores germinate and growth occurs either saprophytically or by invasion of a suitable host plant.

In general, once $F$ oxysporum has penetrated the host plant, the fungus moves into the vascular tissue. When juvenile roots are the site of infection, the fungus moves either intercellularly or intracellularly to the developing xylem vessel elements and invades them before they are fully mature. The pathogen is generally confined to the xylem parenchyma cells at an early stage of disease development. The pathogen is spread throughout the plant by means of mycelial growth or conidia, primarily microconidia, produced in infected xylem vessel elements. Following root penetration, the invading hyphae of all tracheal fungal pathogens are reported to grow through root tissue towards the stele. Once inside the vascular system, the fungus may change its mode of nutrition to adapt to the nutrient conditions in the vessel lumen. As disease development progresses, the fungus may invade tissues adjacent to the xylem.

Fusarium wilt pathogens can survive in the absence of susceptible host plants by invasion and colonization of other plants that show few, if any, disease symptoms. When pea cultivars, differing by a single gene for resistance or susceptibility to race 1 or 5 of $F$ oxysporum f sp pisi, were grown in soil infested with the appropriate pathogen, both races colonized root surface cells of either host (Charchar and Kraft, 1989). Charchar and Kraft further stated that each race could be isolated from apices of tap and lateral roots and from excised lateral root ends of the resistant cultivars, but were isolated more frequently from the susceptible cultivars. Lateral roots and stems of resistant cultivars were not invaded internally, in contrast to the equivalent plant parts of susceptible cultivars. Invasion of epicotyls of resistant cultivars was limited as of $20 \mathrm{~d}$ after planting. In comparison, epicotyls of susceptible cultivars were extensively infected by this time. Vascular plugging was found to seal off xylem elements of resistant but not susceptible pea varieties in the lateral roots, epicotyl, and above-ground stems. In contrast, xylem of the susceptible pea cultivars was extensively invaded by mycelium of the pathogen. Xylem fluids collected from excised stems of resistant cultivars inhibited germtube growth but stimulated conidial germination and germtube growth if from susceptible cultivars. Beckman (1987) has stated that vascular colonization by fungal wilt pathogens is extensive in wilt-susceptible plants but remains limited to the basal part of resistant plants. This localization at the base of the plant is also true with peas.

One of the earliest responses to infection by $F$ oxysporum is the deposition within contact cells of additional wall callose material. Deposits in the form of papillae or more extensive apposition layers occur especially at sites of fungal contact (Beckman, 1987). The initiation of the response and the capacity to respond appears to be nonspecific in terms of the inducing organisms, which is inhibited in the resistant plant's response but not in the susceptible reaction. Callose deposition is a very general defense reaction. A strong deposition in infected cells is associated with pathogen failure to become established. Perhaps callose deposition is initiated by glycoproteins from the cell walls of the wilt pathogen.

Numerous theories have been advanced to explain the nature of resistance to wilt in crop plants. These theories include inhibitory root exudates (Buxton, 1957), chemical defenses in the host which cause growth inhibition of the pathogen (Hammerschlag and Mace, 1975; Bell and Mace, 1981; Danko and Corden, 1984), and physical barriers which retard or prevent vascular invasion (Elgersma et al, 1972; Stromberg and Corden, 1980; Beckman and Talboys, 1981; Baayen and Elgersma, 1985).

\section{SEED TRANSMISSION OF THE FUSARIUM WILT PATHOGEN}

Snyder (1932) reported that $F$ oxysporum $f \mathrm{sp}$ pisi race 1 can be transmitted occasionally by seed when harvested from a wilt-infested field. Of 8000 seeds tested only 4 transmitted the wilt pathogen as determined in a field grow-out test. Snyder stated that occasionally small soil particles can lodge in a seed surface indentation and the fungus could be contained therein. Snyder stated that the race 1 pathogen can be isolated from the stem node where the first pod develops on a wilted plant. Although no evidence was presented, it is possible that the pathogen could invade the pedicel and hence the pod and seed. Masheshwari et al (1982) isolated $F$ oxysporum $f$ sp pisi from surface disinfested seed of 6 vari- 
eties grown in the Hoshiarpur district of Punjab, India, where pea root rot and wilt are a problem. The isolates of $F$ oxysporum recovered were pathogenic but the authors did not classify these isolates to any race using differential varieties.

It is the author's opinion that true internal seed transmission of the pea wilt pathogen depends upon plant age when wilt symptoms are expressed. The probability of seed transmission of the race 2 pathogen, which attacks a pea plant at flowering to pod development, is much higher than for race 1,5 , or 6 which usually kill a susceptible plant before bloom.

\section{REFERENCES}

Armstrong GM, Armstrong JK (1974) Races of Fusarium oxysporum $\mathrm{f} \mathrm{sp}$ pisi, causal agents of wilt of peas. Phytopathology 64, 849-857

Baayen RP, Elgersma DM (1985) Colonization and histopathology of susceptible and resistant carnation cultivars infected with Fusarium oxysporum $\mathrm{f} p \mathrm{p}$ dianthi. Neth J Plant Pathol 91, 119-135

Beckman CH (1987) The Nature of Wilt Diseases of Plants. Am Phytopath Soc, Saint-Paul, MN, USA

Beckman CH, Talboys PW (1981) Anatomy of resistance. In: Fungal Wilt Diseases of Plants (ME Mace, AA Bell, $\mathrm{CH}$ Beckman, eds) Academic Press, New York, USA, 487-521

Bell AA, Mace ME (1981) Biochemistry and physiology of resistance. In: Fungal Wilt Diseases of Plants (ME Mace, AA Bell, $\mathrm{CH}$ Beckman, eds), Academic Press, New York, USA, 431-486

Bolton AT, Nutall VW, Lyal LH (1966) A new race of Fusarium oxysporum $f$ pisi. Can J Plant Sci 46, 343347

Buxton EW (1957) Some effects of pea root exudates on physiologic races of Fusarium oxysporum $\mathrm{f}$ pisi (Lindf) Snyder and Hansen. Trans Br Mycol Soc 40, 145-154

Charchar M, Kraft JM (1989) Response of near-isogenic pea cultivars to infection by Fusarium oxysporum $f \mathrm{sp}$ pisi races 1 and 5. Can J Plant Sci 69, 1335-1346

Coddington A, Matthews PM, Cullis C, Smith $\mathrm{KH}$ (1987) Restriction digest patterns of total DNA from different races of Fusarium oxysporum $f$ sp pisi. An improved method for race classification. J Phytopath 118, 9-20

Correll JC (1991) The relationship between formae speciales, races and vegetative compatibility groups in Fusarium oxysporum. Phytopathology 81, 10611064

Danko SJ, Corden ME (1984) Effect of ethanol on the accumulation of antifungal compounds and resistance of tomato to Fusarium oxysporum f sp lycopersici. Phytopathology 74, 1475-1479
Doling DA (1963) Effect of root damage on the development of Fusarium wilt in peas. Trans $\mathrm{Br} \mathrm{Mycol}$ Soc 46, 577-584

Elgersma DM, MacHardy WE, Beckman CH (1972) Growth and distribution of Fusarium oxysporum $\mathrm{f} s \mathrm{~s}$ lycopersici in near-isogenic lines of tomato resistant or susceptible to wilt. Phytopathology 621232 1237.

Goth RW, Webb RE (1981) Sources and genetics of host resistance in vegetable crops. In: Fungal Wilt Diseases of Plants (ME Mace, AA Bell, $\mathrm{CH}$ Beckman, eds) Academic Press, New York, USA, 377-411

Haglund WA (1974) Race concept in Fusarium oxysporum f pisi. Pisum Genetics News/6, 20-21

Haglund WA (1984) Fusarium wilts. In: Compendium of Pea Diseases (DJ Hagedorn, ed), Am Phytopath Soc, Saint-Paul, MN, USA, 22-24

Haglund WA (1989) A rapid method for inoculating pea seedlings with Fusarium oxysporum $\mathrm{f} s p$ pisi. Plant Dis $73,457-458$

Haglund WA, Kraft JM (1970) Fusarium oxysporum $\uparrow$ pisi race 5. Phytopathology 60, 1861-1862

Haglund WA, Kraft JM (1979) Fusarium oxysporum $f$ sp pisi race 6: Occurrence and distribution. Phytopathology 69, 818-820

Hammerschlag F, Mace ME (1975) Antifungal activity of extracts from Fusarium wilt-susceptible and resistant tomato plants. Phytopathology 65, 93-94

Hare WW, Walker JC, Delwiche EJ (1949) Inheritance of a gene for near wilt resistance in the garden pea. $J$ Agric Res 78, 239-250

Huebbeling $N$ (1974) Testing for resistance to wilt and near wilt of peas caused by race 1 and 3 of Fusarium oxysporum f pisi. Medd Fakult Landbouwwetenschappen Gent 29, 991-1000

Huisman OC (1982) Interrelationships of root growth dynamics to epidemiology of root-invading fungi. Ann Rev Phytopathol 20, 303-327

Jones FR, Linford MB (1925) Pea Disease Survey in Wisconsin. Wisc Agric Exp Sta Res Bull, WI, USA, $64,31 \mathrm{p}$

Kerr A (1963) The root rot-Fusarium wilt complex of peas. Aust J Biol Sci 16, 55-59

Kistler HC, Momol EA, Benny U (1991) Repetitive genomic sequences for determining relatedness among strains of Fusarium oxysporum. Phytopathology 68, 331-336

Komada H (1975) Development of a selective medium for quantitative isolation of Fusarium oxysporum from natural soil. Rev Plant Prot Res 8, 114-124

Kraft JM (1978) Effects of root rot pathogens on Fusarium wilt of peas. Plant Dis Rep 62, 216-221

Kraft JM, Haglund WA (1978) A reappraisal of the race classification of Fusarium oxysporum $\mathrm{f} \mathrm{sp}$ pisi. Phytopathology 68, 273-275

Kraft JM, Muehlbauer FJ, Cook RJ, Entemann FM (1974) The reappearance of common wilt of peas in eastern Washington. Plant Dis Rep 58, 62-64 
Linford MB (1928) A Fusarium Wilt of Peas in Wisconsin. Wisc Agric Exp Sta Res Bull WI, USA, $85,43 \mathrm{p}$

Masheshwari SK, Gupta JS, Jhooty JS (1982) Role of seed mycoflora of pea in the wilt and root-rot complex and its pathogenicity. Agric Sci Digest 2, 196198

Nash SM, Snyder WJ (1962) Quantitative estimations by plate counts of propagules of the bean root rot Fusarium in field soils. Phytopathology 52, 567-572

Nelson PE (1981) Life cycle and epidemiology of Fusarium oxysporum. In: Fungal Wilt Diseases of Plants (ME Mace, AA Bell, CH Beckman, eds), Academic Press, New York, USA, 51-80

Nyvall RF, Haglund WA (1972) Sites of infection of Fusarium oxysporum $f \mathrm{sp}$ pisi race 5 on peas. Phytopathology 62, 1419-1424

Puhalla JE (1985) Classification of strains of Fusarium oxysporum on the basis of vegetative compatibility. Can J Bot 63, 179-183

Schippers B, Voetberg JS (1969) Germination of chlamydospores of Fusarium oxysporum $\mathrm{f} \mathrm{sp}$ pisi race 1 in the rhizosphere, and penetration of the pathogen into roots of a susceptible and a resistant pea cultivar. Neth J Plant Pathol 75, 241-258

Schreuder JC (1951) Een oderzoek over de Amerikaanse vaatziekte van de erwten in Nederland. Rijdschr Plantenziekten 57, 175-206

Snyder WC (1932) Seed dissemination in Fusarium wilt of pea. Phytopathology 22, 253-257
Snyder WC (1933) A new vascular Fusarium wilt disease of peas. Science 77, 327

Stromberg EL, Corden ME (1980) Scanning electron microscopy of Fusarium oxysporum $\mathrm{f} s \mathrm{sp}$ lycopersici in xylem vessels of wilt-resistant and susceptible tomato plants. Can J Bot 58, 2360-2366

Toussoun TA, Nelson PE (1976) Fusarium: A Pictorial Guide to the Identification of Fusarium Species. Penn State Univ Press, Univ Park, PA, USA, $43 p$

Virgin WJ, Walker JC (1940) Relation of the near wilt fungus to the pea plant. J Agric Res 60, 241-248

Wade BL (1929) The Inheritance of Fusarium Wilt Resistance in Canning Peas. Wisc Agric Exp Stn Bull WI, USA, 97, 32 p

Walker JC (1935) A study of resistance to Fusarium wilt in Alaska peas. Am J Bot 22, 849-857

Wells DG, Hare WW, Walker JC (1949) Evaluation of resistance and susceptibility in garden peas to near wilt in the greenhouse. Phytopathology 39 , 771-779

Whalley WM, Taylor GS (1976) Germination of chlamydospores of physiologic races of Fusarium oxysporum $f$ pisi in soil adjacent to susceptible and resistant pea cultivars. Trans $\mathrm{Br} M y c o l$ Soc 66, 713

Williams JGK, Kubelik AR, Livak KJ, Rafalski JA, Tingey SV (1990) DNA polymorphisms amplified by arbitrary primers are useful as genetic markers. Nucleic Acids Res 18, 6531-6535 